Ilmu Pertanian (Agricultural Science)

Vol. 2 No. 2 August, 2017 : 085-092

Available online at http://journal.ugm.ac.id/jip

DOI: doi.org/10.22146/ipas.17668

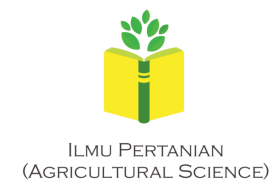

\title{
Growth Response of Carrot (Daucus Carota) Local and Hybrids Varieties on Different $\mathrm{Pb}$ Doses
}

\author{
Boy Indra Permata, Nasrez Akhir, Zulfadly Syarif \\ Department of Agronomy, Faculty of Agriculture, University of Andalas \\ Kampus Unand Limau Manih, Limau Manis, Pauh, Kota Padang, Sumatera Barat 25163, Indonesia \\ *Corresponding email: boypr.75@gmail.com
}

Received: $5^{\text {th }}$ January 2017 ; Revised: 22 $2^{\text {nd }}$ March 2017 ; Accepted: $28^{\text {th }}$ August 2017

\begin{abstract}
This research aimed to analyse the growth and yield of local and hybrid carrots (Daucus carota) on various heavy metal $(\mathrm{Pb})$ doses. The experiments had been done in Nagari Situjuah Limo Nagari, Kabupaten Lima Puluh Kota from August to December 2015. The purpose of this experiment was to obtain the safe doses of $\mathrm{Pb}$ for growth and yield of carrots as food consumption. Treatments were arranged in a split plot design with three replications. The treatments were four doses of $\mathrm{Pb}(0,100,200$ and $300 \mathrm{mg} / 10 \mathrm{~kg}$ soil) and varieties (local and hybrid carrots). Data were analysed by variance analysis $\alpha=1 \%$, and Duncan's Multiple Range Test (DMRT) with $\alpha=1 \%$. The results showed that various doses of heavy metal $\mathrm{Pb}$ affected significantly different of $\mathrm{Pb}$ content in leaves, yields, and chlorophyll. Local and hybrid carrots had significantly difference in plant height, long leaves, yields weight and diameter, $\mathrm{Pb}$ doses in leaves and yields and chlorophyll. $\mathrm{Pb}$ contamination levels in leaves and the leaves exceeded the limits set by Indonesian National Standard (SNI)
\end{abstract}

Keywords: Carrot, Growth, Pb, Yields

\section{INTRODUCTION}

Plants can be a deployment mediator of heavy metals in living beings due to the inclusion of these metals in plants through the roots and stoma. Vegetables, both as food and feed, have been displaced therein exposed metal such as lead, cadmium, chromium and zinc into the body other living things (Farida et al., 2004).

Plants have the ability to absorb ions from the environment through the cell membrane. Two properties of ion uptake by plants are (1) the concentration factor, namely the ability of plants to accumulate ions to a certain concentration level, and may even achieve some level greater than the concentration of ions in the medium; and (2) a quantitative difference will need different nutrients to each plant species (Fitter and Hay, 1991).

Heavy metals are absorbed through the roots into the plant tissue, which would then entered the food chain cycle (Alloway, 1990). Metals accumulate in the tissues and may cause toxicity to humans, animals, and plants when its content exceeds the tolerance limit. The process of absorption of toxins, including heavy metals, according to
Soemirat (2003) may occur through some parts of the plant, namely: (1) roots, especially for inorganic and hydrophilic substances; (2) leaves, for lipophilic substances; and (3) stomata for gas. The absorption process itself occurs in animals with different mechanisms of diffusion, only the terms used are different, the translocation. This transport occurs from cell to cell to the vascular network in order to be distributed to all parts of the plant. Catalytic diffusion bonding occurs with yarns cytoplasm called plasmadesmata. For instance, transport of nutrients from roots to leaves and the reverse transport of food or hydrates of carbon from leaves to roots.

In the Decree of the Director General of Drug and Food Control Number: 03725 / BSK / VII / 89 about the maximum levels of metal contamination in food, stated that the contamination levels of $\mathrm{Pb}$ for fruit commodity and processed products is $2.0 \mathrm{ppm}$. Meanwhile, based on the Indonesian National Standard (SNI) No. 7387: 2009 about heavy metal contamination of food ingredients in food, for fruit and vegetable commodities is $0.5 \mathrm{mg} / \mathrm{kg}$.

The purposes of this study are: to understand the growth and yield response of local varieties and 
hybrids carrots in the addition of $\mathrm{Pb}$; to find out the concentration of $\mathrm{Pb}$ which has significant effect to the growth and yield of local varieties and hybrids carrots; to find out how the content of heavy metals contained in the tubers of local and hybrids varieties of carrot.

\section{MATERIALS AND METHODS}

Materials used in this experiment were soil, carrot seed of Kuroda EW Select variety (PT. East West Seed), and local carrot seeds of Bukittingi. Chemicals used in this study were $\mathrm{Pb}\left(\mathrm{NO}_{3}\right)_{2}$ in powder form, $\mathrm{H}_{2} \mathrm{O}_{2}, \mathrm{HNO}_{3}, \mathrm{HClO}_{4}$, acetone, and perchloric acid.

Some tools such as hoes, machetes, cropping scissors, scale, polybag, paper labels, $\mathrm{pH}$ meter, analytical balance, filter paper, flask, pipette volume, measuring cups, blender, desiccator, oven, ultrasonic bath, erlenmeyer, spoon polyethylene, polyethylene bottles, spray bottles, electric heating (hot plate), and Atomic Absorption Spectrophotometer (AAS) were used in this research.

\section{Sampling}

Sampling methods for harvesting local and hybrids varieties of carrots were conducted randomly in experimental plots in a farmland in Kenagarian Situjuah Banda Nagari Limo Situjuh, the District Lima Puluh Kota. This sampling was conducted in November 2015.

\section{Treatment of samples}

Samples were washed thoroughly with distilled water, then cut into small pieces. The sample was then oven-dried at a temperature of $60{ }^{\circ} \mathrm{C}$ for 24 hours or until it reached a constant weight. Dried samples then mashed into powder.

\section{Sample preparation}

Sample was carefully weighed as much as 1 gram of powder samples and put in a $100 \mathrm{~mL}$ glass beaker. Added $10 \mathrm{~mL}$ of concentrated $\mathrm{HCl}: \mathrm{HNO}_{3}$ mixture with $3: 1$ ratio, then sonicated with ultrasonic bath for 45 minutes at a temperature of $60{ }^{\circ} \mathrm{C}$. Sonication results then heated on a hotplate for 45 minutes at a temperature of $140{ }^{\circ} \mathrm{C}$, cooled, and filtered. Digestion results then made into a $50 \mathrm{~mL}$, then was taken $10 \mathrm{~mL}$, and then diluted to a volume of $50 \mathrm{~mL}$. The filtrate was then measured by atomic absorption spectrophotometer-photometer.

\section{Making the calibration curve}

A calibration curve was made by plotting the absorbance versus the concentration of standard solutions which had been made, then linear line showing the correlation between the absorbance and the standard solution concentration was drawn. Each solution was measured its $Y$ absorbance at $217.0 \mathrm{~nm}$ for $\mathrm{Pb}$.

\section{The Determination of the Concentration of $\mathbf{P b}$}

The solution extracts of sample was measured by AAS with a slit width of $1 \mathrm{~nm}$ to $\mathrm{Pb}$. Determination of $\mathrm{Pb}$ concentration in the samples was done by using a calibration curve in the form of linear line, so we could determine the concentration of the metal from the measured absorbance. The actual concentration of the metal in the sample could be determined using the following calculation:

Clear extract measured by AAS using a standard series of metallic lead $(\mathrm{Pb})$ as a comparison.

Metal levels curve $=$ ppm x ml extract $/ 1000 \mathrm{ml}$ $\mathrm{x}$ (1000 g sample/gr examples) $\mathrm{x}$ fk.

$=$ ppm curve $\mathrm{ml} \times 25 / 1000 \mathrm{x}$ $1000 \mathrm{~g} / 5 \mathrm{~g}$.

$=$ ppm curve $\mathrm{x} 5 \mathrm{x} \mathrm{fk}$.

ppm curve $=$ levels sample obtained from the curve

Determination of Chlorophyll Content

Measurements were performed by measuring the leaf samples with spectrophotometer. The leaves were measured as much as 10 leaves per plant with 1 gram of weight.

Five gram of leaf sample was extracted with acetone $85 \%$, then centrifuged at $1500 \mathrm{rpm}$ for $10 \mathrm{~min}$ utes. Then the filtrate was taken and put into a flask of $100 \mathrm{ml}$-fit with acetone up to the mark.

Enter in the cuvette and measure the absorbance at $645 \mathrm{~nm}$ and $663 \mathrm{~nm}$ wavelength. Chlorophyll was calculated as follows: Chlorophyll $\mathrm{A}=12.7$ (A 663) - 2.69 (A 645); Chlorophyll B = 22.9 (A 645) - 4.68 (A 663); Chlorophyll Total $=20.2($ A 645) $+2.02($ A $663)$.

\section{RESULT AND DISCUSSION}

\section{Plant Height}

The data of carrot plant height in response to $\mathrm{Pb}$ were presented in Table 1. Statistical analysis showed that in general, different varieties of carrots and various heavy metals $\mathrm{Pb}$ doses did not have significant interaction to plant height of carrots. Therefore, there was no interaction between cultivar and $\mathrm{Pb}$ doses. The discussion of this variable was done to each single factor which was tested. The doses of heavy metals $\mathrm{Pb}$ treatment had no significant effect to plant height of carrots, while between varieties showed a significant different in plant height. Effects of heavy 
Table 1. Effect of different varieties and heavy metals $\mathrm{Pb}$ doses to plant height of carrot at $70 \mathrm{HST}$

\begin{tabular}{lccccc}
\hline \multirow{2}{*}{ Varieties } & \multicolumn{4}{c}{ Dose $\mathrm{Pb}(\mathrm{mg} / \mathrm{kg})$} & \multirow{2}{*}{ Mean } \\
\cline { 2 - 5 } & 0 & 10 & 20 & 30 & \\
\hline Local & 99.50 & 96.37 & 97.10 & 96.20 & $97.29 \mathrm{~B}$ \\
Hybrids & 60.17 & 53.67 & 62.83 & 62.03 & $59.68 \mathrm{~A}$ \\
Mean & 79.83 & 75.02 & 79.97 & 79.12 &
\end{tabular}

Remarks: The numbers on the same line followed by the same lowercase letters and numbers in the same column followed by the same capital letter were not significantly different according to DMRT test at level $1 \%$.

Table 2. Effect of carrot varieties and various heavy metals $\mathrm{Pb}$ doses interaction to the plant leaves the number of strands of carrots

\begin{tabular}{lcccccccc}
\hline \multirow{2}{*}{ Varieties } & \multicolumn{8}{c}{ Dose $\mathrm{Pb}(\mathrm{mg} / \mathrm{kg})$} \\
\cline { 2 - 8 } & 0 & & 10 & 20 & & 30 & \\
\hline \multirow{2}{*}{ Local } & 11.33 & $\mathrm{a}$ & 12.00 & $\mathrm{a}$ & 10.33 & $\mathrm{~b}$ & 9.67 & $\mathrm{~b}$ \\
& $\mathrm{~A}$ & & $\mathrm{~A}$ & $\mathrm{~B}$ & $\mathrm{~B}$ & \\
\hline \multirow{2}{*}{ Hybrids } & 9.67 & $\mathrm{~b}$ & 8.00 & $\mathrm{c}$ & 11.67 & $\mathrm{a}$ & 11.33 & $\mathrm{a}$ \\
& $\mathrm{B}$ & & $\mathrm{B}$ & $\mathrm{A}$ & $\mathrm{A}$ &
\end{tabular}

Remarks: The numbers on the same line followed by the same lowercase letters and numbers in the same column followed by the same capital letter were not significantly different according to DMRT test at level 1\%.

metals $\mathrm{Pb}$ doses and carrot varieties to plant height at this trial were shown in Table 1.

Table 1 showed that there was no significant different $\mathrm{Pb}$ dose to plant height. Local and hybrids varieties had different response to high $\mathrm{Pb}$ content in plant. Local varieties reached $97.29 \mathrm{~cm}$ in height, while hybrids reached $59.68 \mathrm{~cm}$. Genetic influence contributed to plant height difference.

Dwidjoseputro (1998) stated that a plant would grow well and flourish when all the nutrients were in sufficient quantities and available for plants. Lingga and Marsono (2005) also noted that if the nutrients were available in sufficient quantities, the result of metabolism, such as the synthesis of biomolecules, would increase. This led to cell division, elongation, and the maturation of the network became more perfect and quick, thus the volume and weight gain more quickly, which in turn caused a better plant growth.

There was no significant interaction of varieties and $\mathrm{Pb}$ doses to the length of the leaves. Various doses of heavy metals $\mathrm{Pb}$ did not cause a significantly different effect to the leaf length, but different varieties showed a significant influence to the length of the leaf.

The local varieties without the provision of heavy metals had long leaves that are highs and lows in the treatment of hybrid varieties by administering $10 \mathrm{mg} / \mathrm{kg}$
Table 3. Interaction effect of various $\mathrm{Pb}$ doses treatment and carrot varieties to $\mathrm{Pb}$ content in plant leaves

\begin{tabular}{lcccc}
\hline \multirow{2}{*}{ Varieties } & \multicolumn{4}{c}{ Dose $\mathrm{Pb}(\mathrm{mg} / \mathrm{kg})$} \\
\cline { 2 - 5 } & 0 & 10 & 20 & 30 \\
\hline \multirow{2}{*}{ Local } & $0.04 \mathrm{~d}$ & $0.06 \mathrm{c}$ & $0.10 \mathrm{a}$ & $0.08 \mathrm{~b}$ \\
& $\mathrm{~A}$ & $\mathrm{~B}$ & $\mathrm{~B}$ & $\mathrm{~B}$ \\
\hline \multirow{2}{*}{ Hybrids } & $0.04 \mathrm{~d}$ & $0.11 \mathrm{~b}$ & $0.12 \mathrm{a}$ & $0.10 \mathrm{c}$ \\
& $\mathrm{A}$ & $\mathrm{A}$ & $\mathrm{A}$ & $\mathrm{A}$ \\
\hline
\end{tabular}

Remarks: The numbers on the same line followed by the same lowercase letters and numbers in the same column followed by the same capital letter were not significantly different according to DMRT test at level $1 \%$.

Table 4. Results of $\mathrm{Pb}$ doses and carrot varieties to $\mathrm{Pb}$ content $(\mathrm{mg} / \mathrm{kg})$ in the carrot bulbs

\begin{tabular}{lcccc}
\hline \multirow{2}{*}{ Varieties } & \multicolumn{4}{c}{ Dose $\mathrm{Pb}(\mathrm{mg} / \mathrm{kg})$} \\
\cline { 2 - 5 } & 0 & 10 & 20 & 30 \\
\hline \multirow{2}{*}{ Local } & $0.077 \mathrm{~d}$ & $0.132 \mathrm{~b}$ & $0.115 \mathrm{c}$ & $0.151 \mathrm{a}$ \\
& $\mathrm{B}$ & $\mathrm{B}$ & $\mathrm{B}$ & $\mathrm{B}$ \\
\hline \multirow{2}{*}{ Hybrids } & $0.106 \mathrm{~d}$ & $0.133 \mathrm{c}$ & $0.162 \mathrm{~b}$ & $0.179 \mathrm{a}$ \\
& $\mathrm{A}$ & $\mathrm{A}$ & $\mathrm{A}$ & $\mathrm{A}$ \\
\hline
\end{tabular}

Remarks: The numbers on the same line followed by the same lowercase letters and numbers in the same column followed by the same capital letter were not significantly different according to DMRT test at level 1\%.

$\mathrm{Pb}$, while the length of leaves on each variety was ranged from 50 to $96 \mathrm{~cm}$. This was caused by the genetic nature of local varieties which were a resistant varieties to environmental influences, especially heavy metals. Because of that, with the application of $\mathrm{Pb}$, local varieties still showed the highest leaf length. Local varieties had been tested in the field and had been adapted to the nature.

According to Connell and Miller (1984), metal contained in the environment would be absorbed by the plant through stomata and root system. Lead entered through stomata, where lead was produced from natural and industrial processes and would combine with the particles in the air and into the plant when stomata opened. Lead absorbed by the roots happened as the roots absorbed water and nutrients.

Based on the analysis of variance of the lraf blade number (on different varieties of carrots treated with heavy metal $\mathrm{Pb}$ ) (Table 2) showed that different varieties of carrots and various dose of heavy metals $\mathrm{Pb}$ was significantly interacted in the number of carrot leaves. Heavy metal $\mathrm{Pb}$ doses and carrot varieties caused an increasing in the number of leaf blade. The plants without $\mathrm{Pb}$ addition showed a higher number of leaves compared with the plants added by $10 \mathrm{mg} / \mathrm{kg}$ of $\mathrm{Pb}$. This clearly showed that the number of leaves from two different varieties 


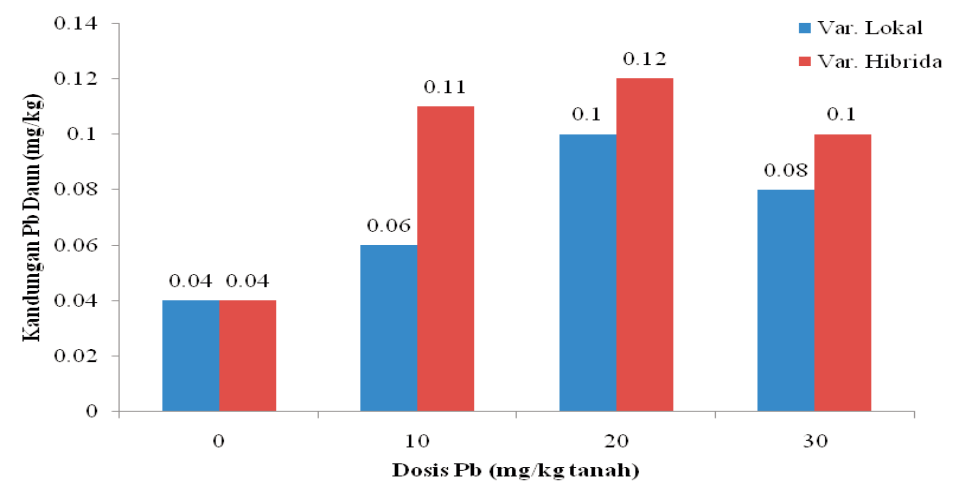

Figure 1. Comparison of $\mathrm{Pb}$ content in leaves of carrot varieties with the application of heavy metal $\mathrm{Pb}$ treatments. $\%$.

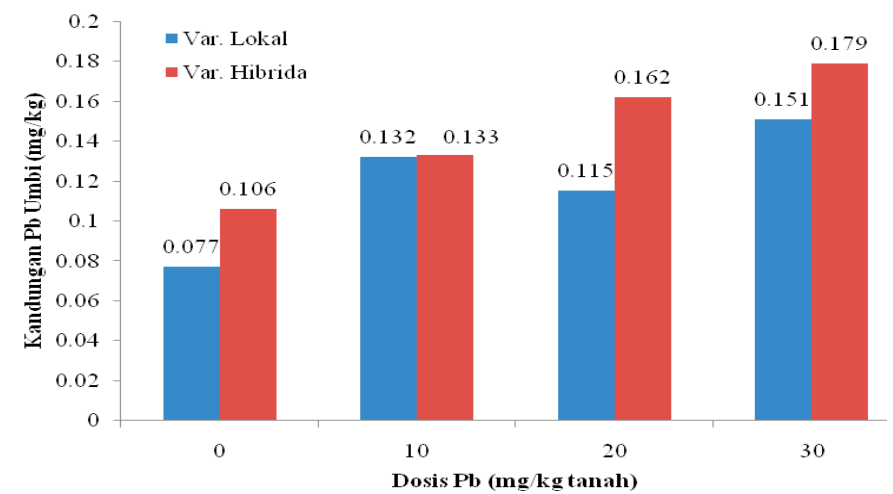

Figure 2. Relationships of carrot varieties and various $\mathrm{Pb}$ dose to the $\mathrm{Pb}$ content in carrot bulbs

Table 5. Effect of administration of various heavy metal $\mathrm{Pb}$ doses and different carrot varieties to tuber weight (grams).

\begin{tabular}{lccccc}
\hline \multirow{2}{*}{ Varieties } & \multicolumn{4}{c}{ Dose $\mathrm{Pb}(\mathrm{mg} / \mathrm{kg})$} & \multirow{2}{*}{ Mean } \\
\cline { 2 - 5 } & 0 & 10 & 20 & 30 & \\
\hline Local & 89.17 & 85.00 & 60.83 & 103.60 & $84.65 \mathrm{~B}$ \\
Hybrids & 175.83 & 150.83 & 174.17 & 186.67 & $171.88 \mathrm{~A}$ \\
Mean & 132.50 & 117.92 & 117.50 & 145.13 & \\
\hline
\end{tabular}

Remarks: The numbers on the same line followed by the same lowercase letters and numbers in the same column followed by the same capital letter were not significantly different according to DMRT test at level 1\%.

Table 6. Effect of various doses of heavy metals $\mathrm{Pb}$ and carrot varieties to bulbs diameter $(\mathrm{cm})$

\begin{tabular}{|c|c|c|c|c|c|}
\hline \multirow{2}{*}{ Varieties } & \multicolumn{4}{|c|}{ Dose $\mathrm{Pb}(\mathrm{mg} / \mathrm{kg})$} & \multirow{2}{*}{ Mean } \\
\hline & 0 & 10 & 20 & 30 & \\
\hline Local & 9.3 & 8.9 & 7.6 & 9.8 & $8.9 \mathrm{~B}$ \\
\hline Hybrids & 13.9 & 13.5 & 14.9 & 14.1 & $14.1 \mathrm{~A}$ \\
\hline Mean & 11.6 & 11.2 & 11.25 & 11.95 & \\
\hline
\end{tabular}

Remarks: The numbers on the same line followed by the same lowercase letters and numbers in the same column followed by the same capital letter were not significantly different according to DMRT test at level 1\%.

varied with the addition of $\mathrm{Pb}$.

Dwidjoseputro (1998) stated that a plant would grow well and flourish when all nutrients were in sufficient quantities and available for plants. Lingga and Marsono (2005) also noted that if the nutrients
Table 7. Effect of Dose Heavy Metals $\mathrm{Pb}$ and Use Carrots Against Several Plant Variety of Chlorophyll Content (ppm)

\begin{tabular}{|c|c|c|c|c|c|}
\hline \multirow{2}{*}{ Varietas } & \multicolumn{4}{|c|}{ Dosis $\mathrm{Pb}(\mathrm{mg} / \mathrm{kg})$} & \multirow[t]{2}{*}{ Rataan } \\
\hline & 0 & 10 & 20 & 30 & \\
\hline Lokal & 0.48 & 0.13 & 0.25 & 0.37 & 0.31 \\
\hline Hibrida & 0.53 & 0.19 & 0.30 & 0.40 & 0.35 \\
\hline Rataan & $0.51 \mathrm{a}$ & $0.16 \mathrm{~d}$ & $0.27 \mathrm{c}$ & $0.38 \mathrm{~b}$ & \\
\hline Remarks: Th & number & on the & $\begin{array}{l}\text { ame line } \\
\text { number }\end{array}$ & followe & $\begin{array}{l}\text { by the same } \\
\text { ame column } \\
\text { t significantly } \\
\text { el } 1 \% \text {. }\end{array}$ \\
\hline
\end{tabular}

the plant were available in sufficient quantities, the result of metabolism, such as the synthesis of biomolecules, would increase. This led to cell division, elongation, and maturation of the network to be more perfect and fast, so that the volume and weight could be gained quickly, which in turn caused a better plant growth.

Analysis results of the $\mathrm{Pb}$ content in leaves of different varieties of carrots treated with heavy metal $\mathrm{Pb}$ showed that different varieties of carrots and various dose of heavy metals $\mathrm{Pb}$ had a significant interaction. Effects of heavy metals $\mathrm{Pb}$ doses and carrot varieties to the content of $\mathrm{Pb}$ in carrot's leave were shown in Table 3 and Figure 1.

Alloway (1990) explained that heavy metals could be absorbed into plant through root tissue and 
leaf stomata, and would enter the food chain cycle. Connell and Miller (1995) explained that leaf surface morphology and chemical character of leaves could affect the entry of $\mathrm{Pb}$ compounds derived motor vehicles. $\mathrm{Pb}$ absorption through leaves occured because $\mathrm{Pb}$ particles in the air fell and settled on the leaves surface and enter through the stomata. Furthermore, Fakuara et al. (1996) mentioned that $\mathrm{Pb}$ contained in plant leaves could be divided into $\mathrm{Pb}$ adsorption and $\mathrm{Pb}$ absorption. Adsorption of $\mathrm{Pb}$ was $\mathrm{Pb}$ which stuck above the leaves surface, and through regular washing with water can be removed from the leaves. While absorption of $\mathrm{Pb}$ was difficult to extract from leaf tissue through ordinary process using water only, because $\mathrm{Pb}$ remained fastened in the plant leaf tissue.

Based on the Decree of the Director General of Drug and Food Control Number: 03725 / BSK / VII / 89 about the maximum levels of metal contamination in food, the contamination levels of $\mathrm{Pb}$ for fruit commodity and processed products was $2.0 \mathrm{ppm}$. Meanwhile, based on the Indonesian National Standard (SNI) No. 7387: 2009 about heavy metal contamination of food ingredients in the food, for the fruit and vegetable commodities was $0.5 \mathrm{mg} / \mathrm{kg}$. From these results, $\mathrm{Pb}$ content in plant leaves of this research was below the set limit (Figure 2). According to Ochiai (1977), mechanisms of poisoning by heavy metals were catagorised into three categories, namely: (1) block or hinder the work of functional groups of biomolecules essential for biological processes, such as proteins and enzymes; (2) replace the metal ions essentially contained in the relevant biomolecules; and (3) hold a modification or change in the form of active groups owned by biomolecules.

\section{The content of $\mathrm{Pb}$ in Bulbs}

Results of the analysis of variance of $\mathrm{Pb}$ contents in tubers showed interaction effects were highly significant. Effects of heavy metals $\mathrm{Pb}$ doses and carrot varieties to the content of $\mathrm{Pb}$ in carrot's bulb were shown in Table 4 . Table 4 showed that the $\mathrm{Pb}$ content of tubers in several doses of $\mathrm{Pb}$ and carrot varieties on test tolerance to carrot plants were significantly different. The analysis results of $\mathrm{Pb}$ content in tubers showed that there was a highly significant interaction with the highest values found in hybrid varieties with a dose of $30 \mathrm{mg} \mathrm{Pb} / \mathrm{kg}$ of $0.179 \mathrm{mg} / \mathrm{kg}$. This result in accordance with Sumpena and Meliani (2005), which stated that the root of carrot were hard to develop in a land with poor soil physical properties.

Based on the Decree of the Director General of
Drug and Food MOH No. 03725 / BSK / VII / 89 about the maximum levels of metal contamination in food, the contamination levels of $\mathrm{Pb}$ for fruit commodity and processed products was $2.0 \mathrm{ppm}$. Based on the Indonesian National Standard (SNI) No. 7387: 2009 about heavy metal contamination of food ingredients in the food, for the fruit and vegetable commodities was $0.5 \mathrm{mg} / \mathrm{kg}$. From these results, $\mathrm{Pb}$ content in tubers from this research was still below the limit set and were safe for consumption.

This condition was caused by the influence of $\mathrm{Pb}$ contents contained in the soil and leaves with the leaching which could be translocated to the tubers. According to Kitagishi and Yamane (1981), Pb contained in the network at the vegetative stage of the plant would be translocated to the tubers during the generative growth phase of the plant. The high content of $\mathrm{Pb}$ in carrot root, possibly due to air pollution containing $\mathrm{Pb}$ absorbed through the carrot-shaped pinnate leaves, bushy, hairy, and rough, as well as in the form of a compound leaf. $\mathrm{Pb}$ absorption could also happen through a land where they were grown, since the sampling was carried out during rainy season. It could caused the particles water-soluble $\mathrm{Pb}$ acidic rain and then absorbed into the ground. This was supported by Dahlan (1989), which stated that the absorption of $\mathrm{Pb}$ could also happen through land, if there was lead in the soil and in the form of soluble compounds in water.

The high content of $\mathrm{Pb}$ in carrot root was possibly due to air pollution containing $\mathrm{Pb}$ absorbed through the carrot-shaped pinnate leaves, bushy, hairy and rough as well as in the form of a compound leaf. $\mathrm{Pb}$ absorption could also happen through a land where they are grown since the sampling carried out during the rainy season so that the particles water-soluble $\mathrm{Pb}$ acidic rain and then absorbed into the ground. This is supported by Dahlan (1989) which states that the absorption of $\mathrm{Pb}$ can also through the land, if there is lead in the soil and in the form of water-soluble compounds.

$\mathrm{Pb}$ content in bulbs in plant with heavy metal application was higher than the control treatment. Tubers of local variety at harvest time had lower $\mathrm{Pb}$ content of $\mathrm{Pb}$ compared with the hybrid variety. This was due to genetic effects of both carrot varieties. This indicated that plant's response to the treatment was determined by nature or genetics. This was supported by Coursey and Ferber (1979) which stated that the root to shoot ratio of harvesting a crop was influenced by genetic factors and also the environment in which it was grown. 


\section{Bulbs Weights}

Results of the analysis of variance of tuber weight showed that different carrot varieties and various heavy metals $\mathrm{Pb}$ dose did not have a significant interaction. Therefore, there was no real interaction, thus the discussion was done for each single factor tested. Various doses of heavy metals $\mathrm{Pb}$ had no significant effect to the tuber weight, but different varieties caused a significant influence to the weight of tuber. Effects of heavy metals $\mathrm{Pb}$ doses and carrot varieties to the tuber weight were shown in Table 5.

Root was a plant organ which determined the growth of plants, for both above ground organ (shoot) and underground (root) (Bohn, 1979). Generally, plants would absorb nutrients dissolved in water or land through its roots (Fitter and Hay, 1991). Plants could absorb $\mathrm{Pb}$ during fertility conditions and low soil organic matter content. In these circumstances, heavy metals $\mathrm{Pb}$ would loose from the soil and in the form of free-moving ions in the soil solution. If other metals were not capable of preventing its existence, there would be a $\mathrm{Pb}$ uptake by plant roots.

The tuber weight results in the treatment of $\mathrm{Pb}$ dose of $10 \mathrm{mg} / \mathrm{kg}$ was higher compared with control. This was due to the provision of an increase in the content of $\mathrm{Pb}$ absorption by the plant. $\mathrm{Pb}$ accumulated in the plant tissue through two ways: absorption through roots and leaves. Lead $(\mathrm{Pb})$ absorbed by the hair roots would experience the binding, inactivation, and precipitation (Lepp, 1978). Lead ( $\mathrm{Pb}$ ) tied by ions in the core of carrot root. Because of the small $\mathrm{Pb}$ translocated to the top of the plant, the absorption of $\mathrm{Pb}$ was very small in tubers. Treatment of various doses of $\mathrm{Pb}$ caused a higher $\mathrm{Pb}$ content in bulbs compared with control treatment. Tubers of local varieties at harvest had smaller $\mathrm{Pb}$ content compared with the hybrid varieties. This was due to genetic effects of both varieties. This indicated that plants still had the same response to the treatment is determined by the nature or genetics. This was supported by Coursey and Ferber (1979) which stated that the root to shoot ratio of harvesting a crop was influenced by genetic factors and also the environment in which it was grown.

\section{Bulbs Length}

Results of the analysis of variance of carrot root length showed that the treatment of different varieties of carrots and various doses of heavy metals $\mathrm{Pb}$ did not cause significant different effect on each factor, as well as a real interaction to the length of carrot root.

Hybrid varieties tended to plant roots penetrate the soil mass was not optimal due to the effect of soil conditions of no-tillage and minimum tillage treatment. Research conducted Barley and Greacen (1967) showed that the development of plant roots was inhibited by the presence of soil mechanical resistance, in the sense of the strength of the higher ground. The plant roots grew and elongated the space between the soil solids, called the pore. No tillage treatment caused the soil to have no pores for the growth of plant roots. In addition to the pore, the effect of soil structure formed as a result of soil tillage was aeration. The availabilities of oxygen and carbon dioxide in the root zone expenditures were important for plants to grow well. According to the research conducted by Visser (1977), the better aeration of the soil, the better the growth of plant roots which would affect the increase in yield.

\section{Bulbs Diameter}

Results from the analysis of variance of carrot root diameter showed that different varieties of carrots and various doses of heavy metals $\mathrm{Pb}$ did not affect the real interaction in carrot root diameter. Therefore, there was no real interaction of influence. The discussion of this variable was done for each single factor tested. Various doses of heavy metals $\mathrm{Pb}$ did not caused a significantly different effect to carrot root diameter, but different carrot varieties caused a significant influence to the diameter of the bulbs. Effect of various doses of heavy metals $\mathrm{Pb}$ and varieties of carrots to the diameter of the bulbs in this research could be seen in Table 6 .

From Table 6, it could be seen that the administration and control of heavy metal with a dose of $10 \mathrm{mg} / \mathrm{kg}$ to $30 \mathrm{mg} / \mathrm{kg}$ did not caused a great difference in tuber diameter size. It was suspected that the application of heavy metals $\mathrm{Pb}$ did not affect carrots receive as a nutrient for the magnification of the tuber, as well as in meeting the needs for growth. Administration of heavy metals $\mathrm{Pb}$ at a dose of $30 \mathrm{mg} / \mathrm{kg}$ per plant showed the greatest bulb diameter in local varieties. Hybrid varieties had the largest bulb diameter when combined with the application of $20 \mathrm{mg} / \mathrm{kg}$ heavy metals $\mathrm{Pb}$. When compared to the average data length of the tuber dosing (Table 6), the diameter of the bulbs with the same dose showed no relationship straight comparisons. The longest tubers did not have the greatest diameter. So this dose did not produce a tuber crop with good quality. Tuber diameter growth was due to genetic effects of both carrot 
varieties. This indicates that the plants still have the same response to the treatment is determined by the nature or genetics. This was supported by Coursey and Ferber (1979) which stated that the root to shoot ratio of harvesting a crop was influenced by genetic factors and also the environment in which it was grown.

\section{Content of Chlorophyll}

Results from the analysis of variance of carrot leaf chlorophyll content showed that various carrot varieties and doses of heavy metals $\mathrm{Pb}$ did not have interaction effect to the carrot leaf chlorophyll content. Therefore, there was no real interaction of influence. The discussion of this variable was done for each single factor tested. Various doses of heavy metal $\mathrm{Pb}$ and different varieties had a highly significant effect to the leaf chlorophyll content. Effect of various $\mathrm{Pb}$ doses and different carrot varieties to plant height in this trial was presented in Table 7.

Effect on carrots with green leaf $\mathrm{Pb}$ provision and use of some varieties of carrots was very significantly lowering the green color. Heavy metals $\mathrm{Pb}$ affected the metal accumulation and decreased the green colour in carrots with genetic influence of carrots, for their antagonistic effect of metal on the color change of leaves (Mangkoedihardjo \& Samudro 2010; Palar, 2008).

This situation was confirmed by the opinion of Olivares (2003), which statedd that the tendency of a decrease in chlorophyll content was in line with the increase of $\mathrm{Pb}$. There was a link between the concentration of $\mathrm{Pb}$ with the changes in total chlorophyll content in the leaves. The total chlorophyll content decreased with the increasing of $\mathrm{Pb}$. Changes in chlorophyll content due to the increase in $\mathrm{Pb}$ concentrations was associated with the damage to the structure of chloroplasts. Chloroplast structure formation was strongly influenced by the mineral nutrients, such as $\mathrm{Mg}$ and Fe. Excessive influx of heavy metals in plants would reduce the intake of $\mathrm{Mg}$ and $\mathrm{Fe}$, causing changes in the volume and number of chloroplasts (Kovacs, 1992).

Colour of plant leaves administered with the addition of metal $\mathrm{Cd}, \mathrm{Ni}$ and $\mathrm{Pb}$ in various concentration in cropping media for getting a pale green was observed, compared with control plants called klorose. The change in green colour of the leaves could be caused by the damage or malfunction of chlorophyll (Pracaya, 2004). The release of lead into the cytoplasm inhibited two enzymes, namely $Y$-aminolevulinic acid hidratase and profobilinogenase which were involved in the biogenesis of chlorophyll (Hampp and Lendzian, 1974).

\section{CONCLUSION}

Response of local and hybrids carrots growth were affaected by $\mathrm{Pb}$ on plant height, leaf length, weight of tuber, and bulb diameter. The concentration of $\mathrm{Pb}$ dose did not affect plant growth, both in local and hybrids varieties, but it gave effect to the content of $\mathrm{Pb}$ in leaves, roots, and chlorophyll. The content of $\mathrm{Pb}$ in leaves was the highest in local varieties, which was $0.10 \mathrm{mg} / \mathrm{kg}$ and hybrid varieties, which was $0.12 \mathrm{mg} / \mathrm{kg}$. Pb content in bulb was the highest for local varieties $(0.151 \mathrm{mg} / \mathrm{kg})$ and hybrid varieties $(0.179 \mathrm{mg} / \mathrm{kg}) . \mathrm{Pb}$ contamination levels in leaves and the leaves exceeded the limits set by Indonesian National Standard (SNI) No. 7387: 2009 which was $0.5 \mathrm{mg} / \mathrm{kg}$.

\section{REFERENCES}

Alloway, B. J. 1990. Heavy Metals in Soil. New York: Jhon Willey and Sons Inc.

Barley, K. P., and E. L. Greacen. 1967. Mechanical Resistance As A Soil Factor Influencing The Growth of Roots and Underground Shoots. Advances in Agronomy, 19: 1-40.

Bohn, W. 1979. Methods of Studying Root System. Berlin: Springer Verlag.

Connell, D. W. and G. J. Miller. Kimia dan Ekotoksikologi Pencemaran, alih bahasa Y. Koestoer. 2006. Jakarta: UI-Press.

Coursey, D. G. and C. E. M. Ferber. 1979. The Processing of Yams. In: D. L. Plucknett, ed., Small-Scale Processing and Storage of Tropical Root Crops. Colorado: Westview Tropical Agriculture Series 1, pp. 189-211

Dwijoseputro, D. 1998. Pengantar Fisiologi Tumbuhan. Jakarta: Gramedia, pp. 232.

Dahlan, E. N. 1989. Hutan Kota Untuk Pengelolaan Peninngkatan Kualitas Lingkungan Hidup. Jakarta: Asosiasi Pengusaha Hutan Indonesia (APHI).

Farida, W. S., Nurjaeni, R. Mutia, dan D. Diapari. 2004. Kemampuan Cerna Kuskus Beruang (Ailurops ursinus) terhadap Pakan Alternatif di Penangkaran. Biosmart, 6: 65-70.

Fakuara, Y., C. Suryadi, dan Achmadi. 1996. Studi Toleransi Tanaman Peneduh Jalan Dan Kemampuan Mengurangi Polusi Udara. Jurnal Penelitian dan Karya Ilmiah, 2 (4):70-79.

Fitter, A. H. dan R. K. M. Hay. 1981. Fisiologi Lingkungan Tanaman, alih bahasa S. Andani dan E. D. Purbayanti. Yogyakarta: Gadjah Mada University Press.

Hampp, R. and K. Lendzian. 1974. Effect of Lead 
Irons on Chlorophyll Syntesis. Naturwissenschaften, 61: 119-218.

Kitagishi, K. and I. Yamane. 1981. Heavy Metal Pollution in Soils of Japan. Tokyo: Japan Scientific Press.

Kovacs, M. 1992. Biological Indicators in Environmental Protection. Kovacs. New York: Ellis Horwood, pp. 207.

Lepp, N. W. 1981. Effect of Heavy Metal Pollution on Plant. Journal of Applications Science, 1: 99-121.

Lingga, P. dan Marsono. 2005. Petunjuk Penggunaan Pupuk. Jakarta: Penebar Swadaya.

Mangkoedihardjo, S. dan G. Samudro. 2010. Fitoteknologi Terapan. Yogyakarta: Graha Ilmu.

Ochiai, E. 1977. Bioinorganic Chemistry: An Introduction. Boston: Allyn and Bacon.

Olivares, E. 2003. The Effect of Lead on Phytochemistry of Tithonia Diversifolio: Exposed to Roadside Automotive Pollution or Grown in Pots of $\mathrm{Pb}$ Suplemented Soil. Brazilian Journal Plant Physiology, 15(3): 149-158.
Palar, H. 2008. Pencemaran dan Toksikologi Logam Berat. Jakarta: PT. Rineka Cipta.

Pracaya. 2004. Hama dan Penyakit Tanaman. Jakarta: Penebar Swadaya.

Soemirat, J. 2003. Toksikologi Lingkungan. Yogyakarta: Gadjah Mada University Press.

Sumpena, I dan S. Meliani. 2005. Pengaruh Dosis Pupuk Organik Kascing dan Jarak Tanam terhadap Pertumbuhan dan Hasil wortel (Daucus Carota L.). Jurnal Agrivigor, 5(1) : 26-33.

Visser, J. 1977. Soil Aeration Capacity, an Index for Soil Structure, Tested Against Yield and Root Development of Apple Trees at Various Soil Treatments and Drainage Conditions. Plant and Soil, 46: 221-237. 